\title{
Cimetidine induces apoptosis in gastric cancer cells in vitro and inhibits tumor growth in vivo
}

\author{
CHENG-GANG JIANG ${ }^{1}$, FU-RONG LIU ${ }^{2}$, MIAO YU ${ }^{1},{\text { JIA-BIN } \text { LI }^{2} \text { and HUI-MIAN XU }}^{1}$ \\ ${ }^{1}$ Department of Oncology, The First Affiliated Hospital; ${ }^{2}$ Department of Cell Biology, \\ China Medical University, Shenyang 110001, Liaoning Province, P.R. China
}

Received September 28, 2009; Accepted November 3, 2009

\section{DOI: $10.3892 /$ or_00000686}

\begin{abstract}
Cimetidine, a histamine-2 $\left(\mathrm{H}_{2}\right)$ receptor antagonist, has been demonstrated to have anticancer effects on various types of malignancies. However, the mechanisms of its action on gastric cancer are not completely understood. This study was designed to investigate its antitumor effect and underlying mechanisms in human gastric cancer SGC-7901 and MGC-803 cells. The MTT assay was used to evaluate cell viability, and flow cytometry, acridine orange staining and transmission electron microscopy were used to detect apoptosis, for cultured cells. The protein expression in cells was evaluated by Western blot analysis and colorimetric assay. Gastric tumors were established by subcutaneous injection of SGC-7901 cells in nude BALB/c mice, and cimetidine was administered to the mice. The size of tumors was monitored and the weight of tumors was examined. The exposure of gastric cancer cells to cimetidine resulted in growth inhibition and the induction of apoptosis in a dose-dependent manner. Activation of the caspase cascade for both the extrinsic and intrinsic pathways were demonstrated in vitro, including caspase- $8,-9$ and -3 . We also found that the expression of Bcl-2 protein decreased and the expression of Bax protein increased which lead to an increase of the Bax/Bcl-2 ratio. In mice bearing SGC-7901 xenograft tumors, administration of cimetidine showed a significant decrease of tumor volumes and tumor weight compared with the control. Our results showed that cimetidine exhibited antitumor effects in gastric cancer cells with an induction of apoptosis.
\end{abstract}

\section{Introduction}

Despite significant advances in cancer research, cancer remains a worldwide health problem and mortality due to cancer remains high (1). Gastric cancer is the second leading

Correspondence to: Dr Hui-Mian Xu, Department of Oncology, The First Affiliated Hospital, China Medical University, Shenyang 110001, Liaoning Province, P.R. China

E-mail: huimianxu@163.com

Key words: cimetidine, stomach neoplasms, apoptosis, nude mice cause of cancer-related death in the world (2) while there appears to be a decreasing trend in occurrence, notably in western countries, it is still commonly reported in China and Japan (3). Even though the prognosis of patients with advanced gastric cancer seems to have improved as a result of the standardization of surgical techniques and recent advances in chemotherapy, the 5-year postoperative survival rate remains low $(4,5)$. In light of these factors, more effective and safer therapeutic strategies for advanced or unresectable gastric cancer are urgently needed.

Cimetidine as a histamine type $2\left(\mathrm{H}_{2}\right)$ receptor antagonist is used to treat patients with peptic ulcers, acid reflux and hypersecretory states (6). It has been shown to improve the survival of patients with colorectal cancer (7-10). Further, positive effects have also been demonstrated in other cancer patients, such as those with renal cell carcinoma (11), malignant melanoma (12) and glioblastoma (13). In 1988, it was reported that post-operative treatment with cimetidine improved survival in gastric cancer patients of all stages (14). Other $\mathrm{H}_{2}$ receptor antagonists, such as ranitidine and famotidine, do not demonstrate such effects (15-17) indicating that cimetidine may exert its effect by enhancing the host immune response against tumor cells $(7,18)$ or by blocking the cell growth-promoting activity of histamine $(10,15,16)$ rather than directly via histamine antagonism. Some studies indicate cimetidine could block the adhesion of colorectal tumor cells to endothelial cells via down-regulation of E-selectin on endothelial cells (19) and increase survival of colorectal cancer patients with high levels of sialyl Lewis antigens, ligand for E-selectin (20). It was demonstrated that cimetidine inhibited the proliferation of human colorectal cancer cells and induced apoptosis in vitro (21). Recent experimental evidence also indicated that cimetidine inhibited NCAM expression and induced apoptosis of human salivary gland tumor cells $(22,23)$. However, it was not previously determined whether cimetidine modulates the apoptotic pathway in gastric cancer cells.

The present study examined the antiproliferative activity of cimetidine and its effect on the apoptosis of gastric cancer cells. Then, the levels of several important proteins that are strongly associated with the signal-transduction pathway of apoptosis were measured to establish the anticancer mechanism of cimetidine. Furthermore, we used a nude mouse model to confirm the antitumor effect of cimetidine in vivo. 


\section{Materials and methods}

Reagents. Cimetidine, dimethyl sulfoxide (DMSO), propidium iodide (PI) and trypsin were purchased from Sigma (St. Louis, MO, USA). RPMI-1640, penicillin, streptomycin and other cell culture supplies were from Gibco BRL (Grand Island, NY, USA). Fetal bovine serum was from Hyclone (Logan, UT, USA). Monoclonal Bcl-2, Bax and actin primary antibodies, as well as second antibody goat anti-mouse $\mathrm{IgG}$ were obtained from Santa Cruz Biotechnology (Santa Cruz, CA, USA). Caspase- $3,-8$ and -9 colorimetric assay kits were purchased from Biovision Research (CA, USA). MTT [3(4,5-dimethylthiazol-2-yl)-2,5-diphenyltrazolium bromide] and acridine orange (AO) were obtained from Fluka (Ronkonkoma, NY, USA).

Cell cultures. Human gastric carcinoma metastatic lymph node cell line, SGC-7901, and normal gastric epithelial cell line, GES-1, were obtained from Cancer Research Institute of Beijing, China. Human gastric mucinous adenocarcinoma cell line, MGC-803, was obtained from the Cell Bank of Shanghai Institute of Cell Biology, Chinese Academy of Sciences (Shanghai, China). They were cultured in RPMI-1640 containing $10 \%$ fetal bovine serum, $100 \mathrm{U} / \mathrm{ml}$ of penicillin, $100 \mu \mathrm{g} / \mathrm{ml}$ of streptomycin at $37^{\circ} \mathrm{C}$ in a humidified atmosphere of $5 \% \mathrm{CO}_{2}$.

MTT assay. Cell viability was assessed using MTT [3-(4,5dimethylthiazol-2-yl)-2,5-diphenyltrazolium bromide] assay. SGC-7901, MGC-803 and GES-1 $\left(5 \times 10^{3}\right)$ cells were seeded in $200 \mu 1$ of RPMI-1640 medium into 96-well plates, and cultured overnight. Then the medium was replaced with fresh RPMI-1640 or the same media containing different concentrations of cimetidine $\left(10^{-5}-10^{-2} \mathrm{M}\right)$. After a further incubation for 24 or $48 \mathrm{~h}, 50 \mu \mathrm{l}$ of MTT (2 mg/ml) was added to each well followed by $4 \mathrm{~h}$ incubation. The medium was discarded and $150 \mu 1$ of dimethyl sulfoxide was added into each well, and incubated for $20 \mathrm{~min}$. The OD490 $\mathrm{nm}$ was measured. The cell viability index was calculated according to the formula: (experimental OD value/control OD value) x $100 \%$.

Flow cytometric analysis. Gastric cancer cells (SGC-7901, MGC-803) were exposed to cimetidine at concentrations of $0,5 \times 10^{-4}, 1 \times 10^{-3}, 5 \times 10^{-3}$ or $1 \times 10^{-2} \mathrm{M}$ for $24 \mathrm{~h}$ in RPMI- 1640 . The attached and floating cells were mixed and washed with PBS. The cells were centrifuged, and the pellets were resuspended with $5 \mathrm{ml}$ of cold $70 \%$ ethanol and fixed overnight at $4^{\circ} \mathrm{C}$. The fixed cells were washed twice in PBS. Then $50 \mu 1$ of RNase $(10 \mu \mathrm{g} / \mathrm{ml})$ and $25 \mu 1$ of propidium iodide $(1 \mathrm{mg} / \mathrm{ml})$ were added to the cells for $30 \mathrm{~min}$ at room temperature in the dark. Flow cytometric analysis was performed with a FACS Caliber (FACScalibur; Becton-Dickinson, USA). For each analysis, 10,000 events were collected and analyzed with CellQuest software.

Acridine orange staining. Cimetidine-treated gastric cancer cells and untreated gastric cancer cells were washed with icecold PBS, fixed with $4 \%$ paraformaldehyde for $10 \mathrm{~min}$ at room temperature, washed again with PBS, stained with $200 \mu 1$ of acridine orange solution $(10 \mu \mathrm{g} / \mathrm{ml})$ and incubated in the dark for $5 \mathrm{~min}$. The slides were rinsed briefly with PBS to remove unbound dye, mounted with nail polish and viewed under fluorescence microscope.

Transmission electron microscopy. Glutaraldehyde-fixed gastric cancer cells were post-fixed with $1 \%$ osmium oxide $\left(\mathrm{OsO}_{4}\right)$ in $0.1 \mathrm{M}$ cacodylate buffer $(\mathrm{pH} 7.4)$, dehydrated with alcohol and embedded in resin mixture. Ultrathin sections, collected on nickel grids and conventionally stained with uranyl acetate and lead citrate, were examined with transmission electron microscope.

Western blot analysis of Bcl-2 and Bax. Treated cells were lysed in RIPA buffer (120 mM NaCl, $50 \mathrm{mM}$ Tris, $\mathrm{pH} 7.6$, $0.05 \% \mathrm{NP}-40,1 \mathrm{mM}$ EGTA, $1 \mathrm{mg} / \mathrm{ml}$ leupeptin, $1 \mathrm{mg} / \mathrm{ml}$ aprotinin, $1 \mathrm{mM}$ PMSF, $1 \mathrm{mM} \mathrm{NaVO}$, $1 \mathrm{mg} / \mathrm{ml}$ pepstatin, and $1 \mathrm{mg} / \mathrm{ml}$ okadaic acid). The lysates were clarified by centrifugation at $14,000 \times 10 \mathrm{~min}$ and protein concentrations were estimated by an assay (Bio-Rad). For Western blot analysis, equivalent amount of proteins were analyzed via sodium dodecyl sulfate-polyacrylamide gel electrophoresis and then transferred to polyvinylidene difluoride membrane. Membranes were blocked using 5\% milk in TBS $+0.5 \%$ Tween for $1 \mathrm{~h}$ at room temperature. The membranes were then incubated in primary antibody overnight at $4^{\circ} \mathrm{C}$. They were washed three times in TBS $+0.5 \%$ Tween then incubated for $60 \mathrm{~min}$ in HRP-conjugated secondary antibody and developed with ECL luminescence substrate.

Caspase activity assay. Caspase-3, caspase- 8 and caspase- 9 protease activities were determined using a commercial colorimetric assay kit according to the manufacturer's instructions. Briefly, gastric cancer cells $\left(1 \times 10^{6}\right)$ treated with different concentrations of cimetidine for $24 \mathrm{~h}$ were resuspended in $50 \mu 1$ of chilled cell lysis buffer; cells were then incubated on ice for $10 \mathrm{~min}$ and centrifuged for $1 \mathrm{~min}$ in a microcentrifuge $(10,000 \mathrm{~g})$; then supernatants were transferred (cytosolic extract) to a fresh tube and protein concentration was assayed. Next, diluted $100 \mu \mathrm{g}$ protein was added to $50 \mu \mathrm{l}$ cell lysis buffer for each assay. Subsequently, $50 \mu 1$ of $2 \mathrm{x}$ reaction buffer and $5 \mu 1$ of the $4 \mathrm{mM}$ DEVD-pNA (caspase-3)/IETDpNA (caspase-8)/LEHD-pNA (caspase-9) were added and incubated at $37^{\circ} \mathrm{C}$ for $2 \mathrm{~h}$. Samples were read at $405 \mathrm{~nm}$ in a microliter plate reader.

Animal experiment. This experiment was conducted in accordance with the guidelines issued by the State Food and Drug Administration (SFDA of China). The animals were housed and cared for in accordance with the guidelines established by the National Science Council of China.

Female BALB/c nude mice, 35-40 days old and weighing 20-22 g, were supplied by Shanghai Slac Laboratory Animal Limited Company. The mice were kept under sterile conditions and fed a sterilized mouse diet and water. Animals were anaesthetized via inhalation of isoflurance and a tumor cell suspension of $2 \times 10^{6}$ SGC-7901 cells in $0.1 \mathrm{ml}$ RPMI-1640 was injected subcutaneously into the dorsa of each mouse. When tumors reached around $100 \mathrm{~mm}^{3}$ at about 2 weeks, the mice were randomly assigned to three groups ( $n=5 /$ group). The mice were treated with cimetidine $100 \mathrm{mg} / \mathrm{kg} / 2$ days, 

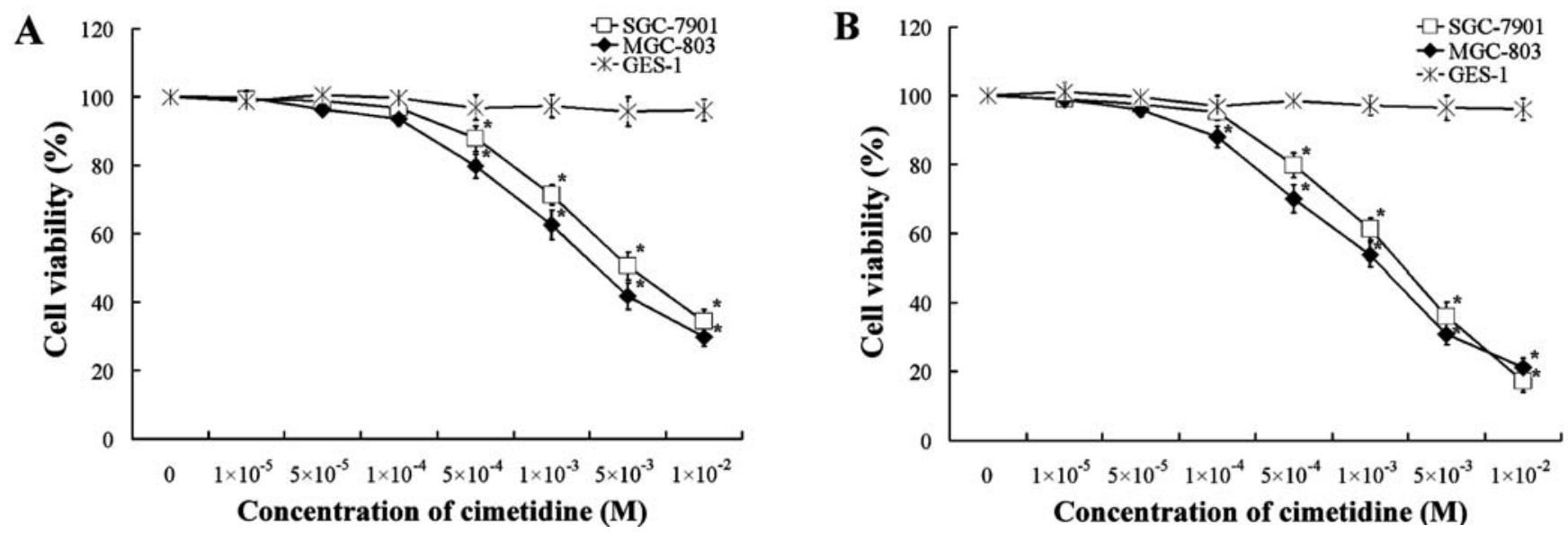

Figure 1. Effect of cimetidine on the proliferation of SGC-7901, MGC-803 and GES-1. Cells were treated with different concentrations of cimetidine for $24 \mathrm{~h}$ (A) and $48 \mathrm{~h}$ (B). The results are expressed as the mean $\pm \mathrm{SD}$ of four independent experiments, ${ }^{*} \mathrm{p}<0.05$ as compared to untreated control.

$200 \mathrm{mg} / \mathrm{kg} / 2$ days or saline (control) by intratumoral injection every other day for 4 weeks. Tumor size was measured once every 4 days in two perpendicular dimensions with vernier calipers and converted to tumor volume using the formula: $\left(a b^{2}\right) / 2$, where $a$ and $b$ refer to the longer and shorter dimensions, respectively. The body weight of the animals was measured once every 4 days at the same time as the tumor dimension measurement and the mortality was monitored daily. After the treatments, all mice were sacrificed and weighed, and tumor was segregated and weighed.

Statistical analysis. All values in the text and figures are presented as mean $\pm \mathrm{SD}$. A one-way analysis of variance (ANOVA) was performed and a Bonferroni's multiple comparison test was applied. Values of $\mathrm{p}<0.05$ were taken to show a significant difference between means.

\section{Results}

Cell growth inhibition. To determine the growth inhibitory activity of cimetidine, gastric cancer cells SGC-7901 and MGC-803 were treated with cimetidine for 24 or $48 \mathrm{~h}$ and viable cells were measured by MTT assay. SGC-7901 and MGC-803 cells exposed to cimetidine resulted in a significant decrease in viable cells in a time- and dose-dependent manner (Fig. 1). Effective concentrations were selected for all further mechanistic studies. Moreover, to confirm whether cimetidine affected normal gastric cells, we also treated normal gastric cell line GES-1 for 24 or $48 \mathrm{~h}$ with the same doses of cimetidine, and MTT assays were carried out. Cimetidine had almost no effect on the growth of normal gastric GES-1 cells.

Induction of apoptosis by cimetidine. In order to determine whether the growth inhibition by cimetidine was associated with apoptosis, gastric cancer cells treated with cimetidine were analyzed for the amount of sub- $\mathrm{G}_{1}$ DNA by flow cytometry of fixed nuclei to quantify the degree of apoptosis. As shown in Fig. 2A, treatment of gastric cancer cells with different concentrations of cimetidine resulted in an increase of the number of apoptotic cells in a dose-dependent manner.
We further examined the morphological changes of gastric cancer cells treated with cimetidine by fluorescence microscopy. The control cells displayed an intact nuclear structure, while cells treated with cimetidine had chromosomal condensation and formation of apoptotic bodies (Fig. 2B). The main ultra-microstructural changes seen in all treated groups were chromatin aggregation, mitochondrial denaturation and apoptotic body formation, as well as cytoplasmic compartments, swelling and disappearance of mitochondrial cristate (Fig. 2C).

The effect of cimetidine on the expression of Bcl-2 and Bax. To further investigate the molecular basis for cimetidineinduced apoptosis in gastric cancer cells, the constitutive expression of typical apoptosis-related proteins Bcl-2 and Bax were analyzed by Western blot. As shown in Fig. 3, the pro-apoptotic protein Bax was induced in cimetidine-treated cells, whereas the expression of antiapoptotic protein Bcl-2 was inhibited after treatment with cimetidine for $24 \mathrm{~h}$. This suggested an increase of Bax/Bcl-2 ratios might be involved in apoptosis induced by cimetidine.

Activation of caspase-3, - 8 and -9 in cimetidine-induced apoptosis. Recent studies have identified caspases as important mediators of apoptosis induced by various apoptotic stimuli (24). Therefore, we examined the activity of caspase-3, -8 and -9 in SGC-7901 and MGC-803 cells treated with cimetidine by colorimetric assay. In addition to executioner caspase-3, initiator caspase- 8 and -9 are also important for apoptosis. The activities of caspase- $3,-8$ and -9 were increased significantly in a dose-dependent manner after treatment with cimetidine (Fig. 4), thus confirming that activated caspase mediates apoptosis in gastric cancer cells upon stimulation with cimetidine.

Cimetidine inhibits the growth of transplantable tumors. Tumor xenografts transplanted by human gastric cancer SGC-7901 cells were used to evaluate the antitumor effect of cimetidine in vivo. Tumors in cimetidine treated mice were visibly smaller than in saline treated mice (Fig. 5A). The tumor volume in cimetidine treated mice was less than in negative 
A

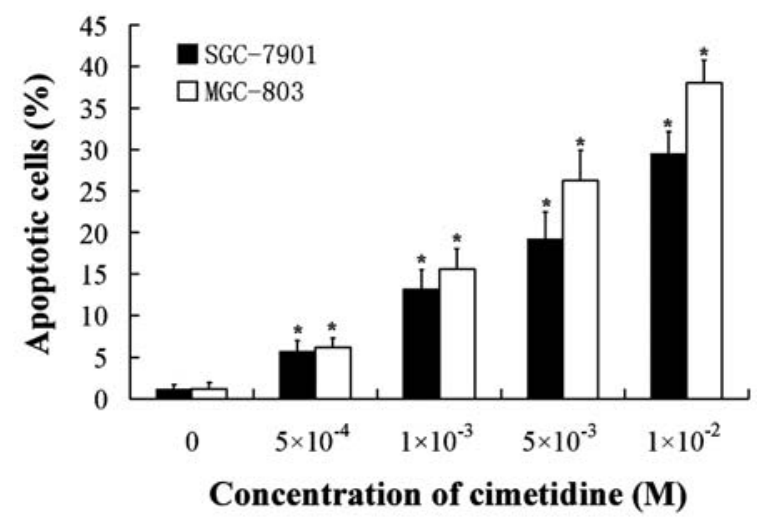

B
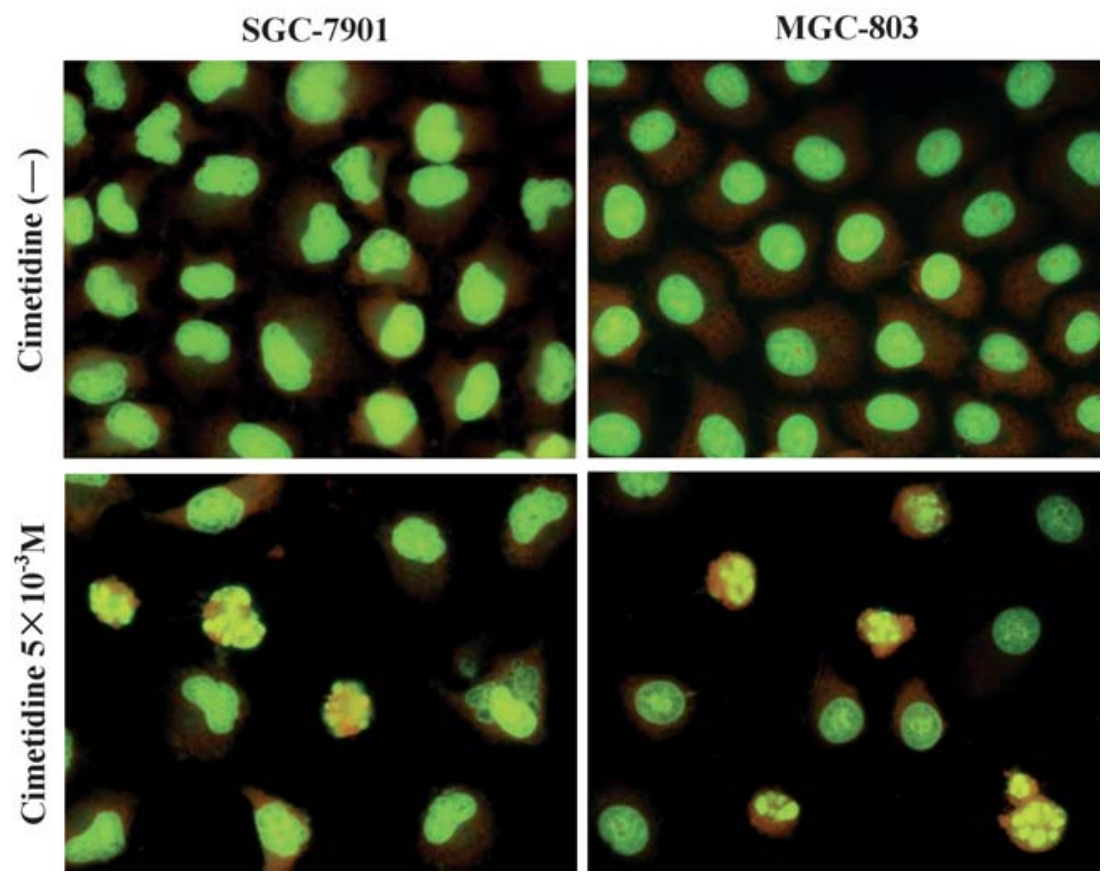

C
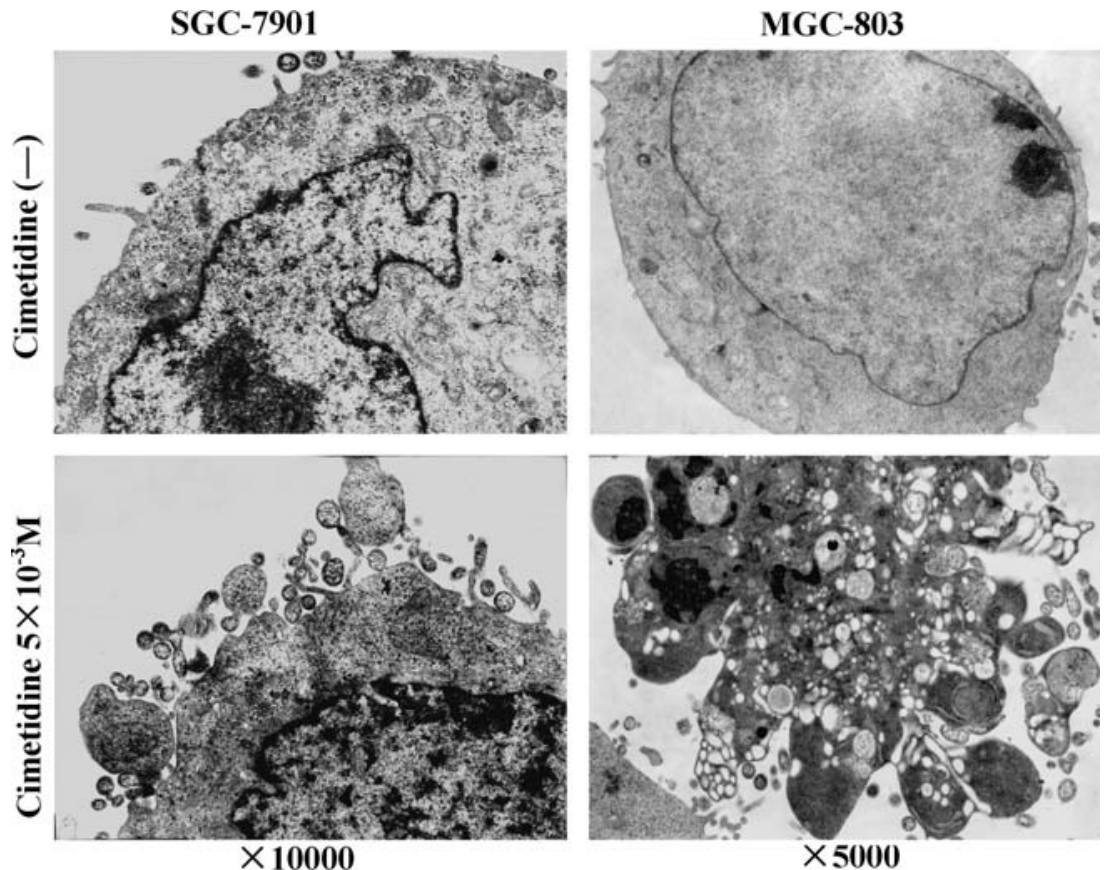

Figure 2. Induction of apoptosis by cimetidine treatment. The cells were treated with various concentrations of cimetidine. (A) The cells were collected and stained with propidium iodide for flow cytometry analysis at $24 \mathrm{~h}$. The results are expressed as the mean \pm SD of four independent experiments, ${ }^{*} \mathrm{p}<0.05$ as compared to untreated control. (B) Detection of nuclear fragmentation in apoptotic gastric cancer cells using acridine orange staining at $24 \mathrm{~h}$. The stained cells were observed under a fluorescent microscope using a blue filter. Magnification, x400. (C) Morphology change of apoptosis in human gastric cancer cells induced by cimetidine under transmission electron microscope at $48 \mathrm{~h}$. 

A
B

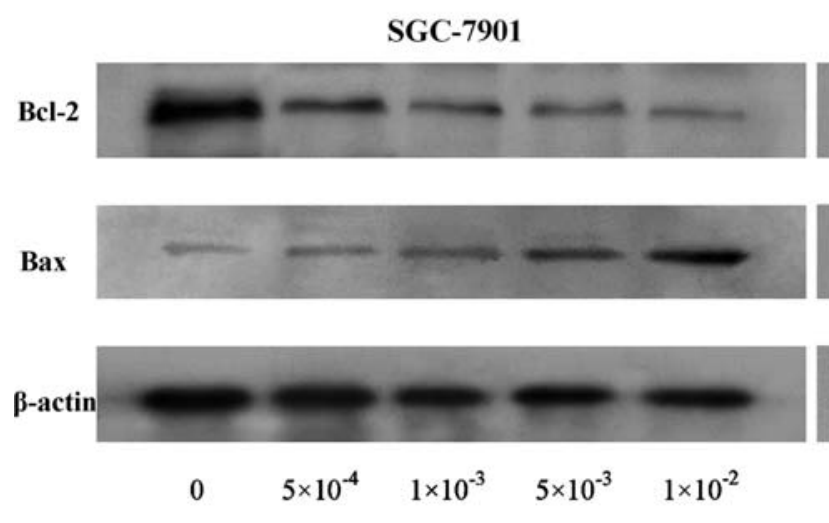

Concentration of cimetidine (M)
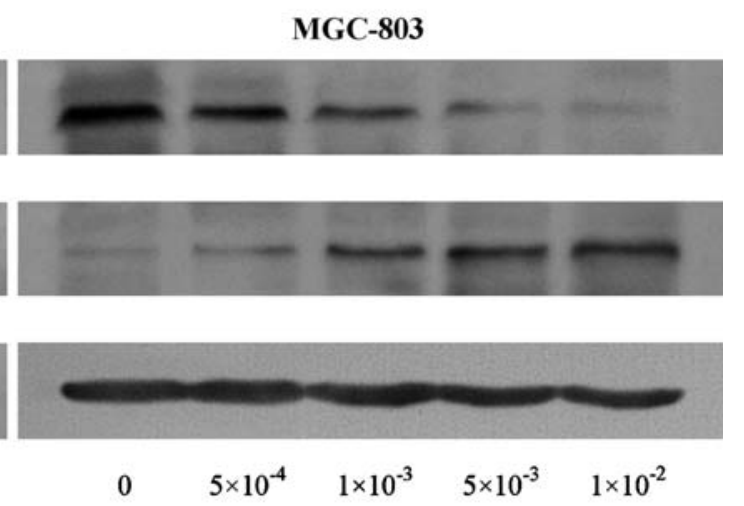

Concentration of cimetidine (M)

Figure 3. Effects of cimetidine on the expression of Bcl-2 and Bax in SGC-7901 cells (A) and MGC-803 cells (B). Cells were treated with various concentrations of cimetidine for $24 \mathrm{~h}$. Western blots for each protein were done at least twice using independently prepared lysates.
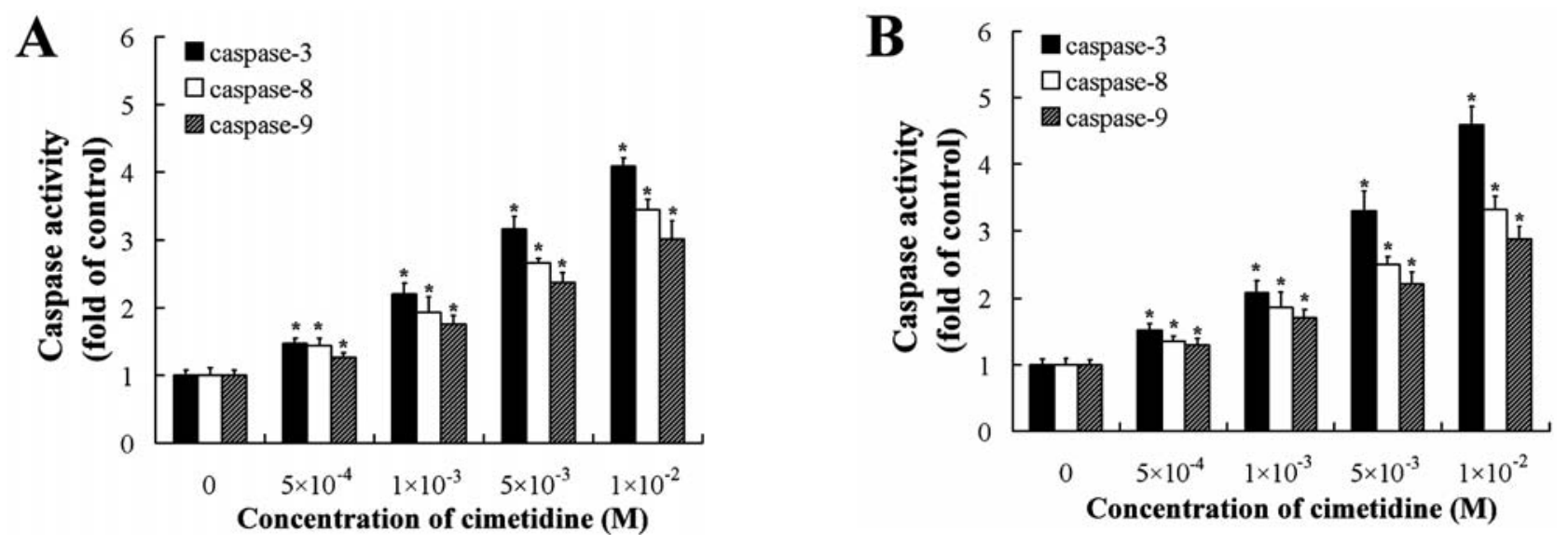

Figure 4. Colorimetric assay for caspase-3, -8 , -9 activities at $24 \mathrm{~h}$ with cimetidine treatment. (A) SGC-7901; (B) MGC-803. The results are expressed as the mean $\pm \mathrm{SD}$ of three independent experiments, ${ }^{*} \mathrm{p}<0.05$ as compared to untreated control.

control mice at the same measurement day (Fig. 5B), indicating that cimetidine significantly inhibited tumor growth during the 4-week treatment. As shown in Fig. 5C, the weight of tumors was also reduced significantly with cimetidine treatment, while the body weight of the mice in cimetidine groups remained essentially unchanged (Fig. 5D). None of the mice died during the treatment.

\section{Discussion}

Cimetidine is widely used to treat peptic ulcers and has also been shown to have clinical benefits in cancer patients. Previous studies have identified antitumor effects and a number of mechanisms of activity, such as direct inhibition of tumor growth, stimulation of host immune response and inhibition of cell adhesion to endothelial cells. A multicenter, randomized, double-blind, placebo-controlled study carried out by Tønnesen et al (14) on 181 patients showed that a post-operative course of cimetidine at a normal therapeutic dosage significantly prolonged the survival of gastric cancer patients. Although the cell-killing mechanism of cimetidine has been suggested $(21,22)$, little is known of the effects of this compound on the growth of gastric cancer cells. This study, therefore, examined whether or not cimetidine induced apoptosis in gastric cancer cells and the mechanism related to cell death. Moreover, we used a nude mouse model to confirm the antitumor effect of cimetidine in vivo.

It was found that cimetidine dose-dependently inhibited the cell viability and induced apoptosis in human gastric cancer cells SGC-7901 and MGC-803. In contrast, cimetidine had almost no effect on the growth of normal gastric cell GES-1. The induction of apoptosis by cimetidine was confirmed by flow cytometry and the characteristic morphological changes. Further experiments showed that the cimetidine treatment significantly decreased the level of antiapoptotic $\mathrm{Bcl}-2$ protein expression and increased the level of pro-apoptotic Bax protein expression, thus shifting the $\mathrm{Bax} / \mathrm{Bcl}-2$ ratio in favor of apoptosis (Fig. 3). The cimetidine 
A

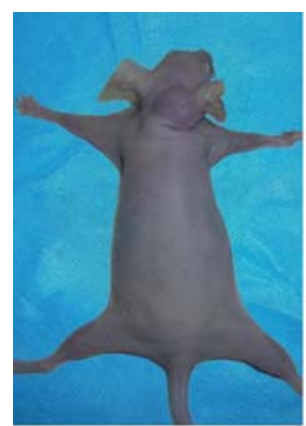

Cimetidine $200 \mathrm{mg} / \mathrm{kg}$

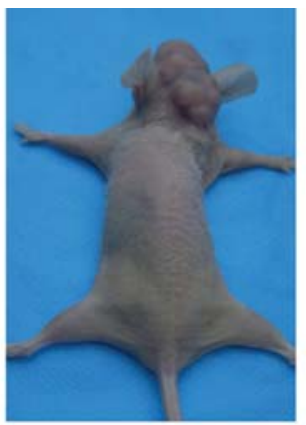

Cimetidine $100 \mathrm{mg} / \mathrm{kg}$

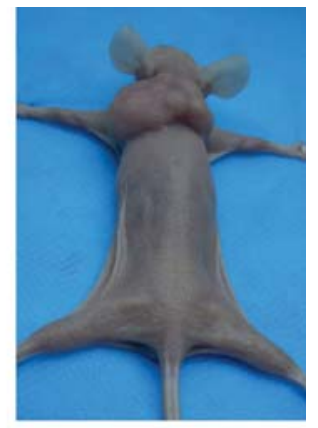

Control
B

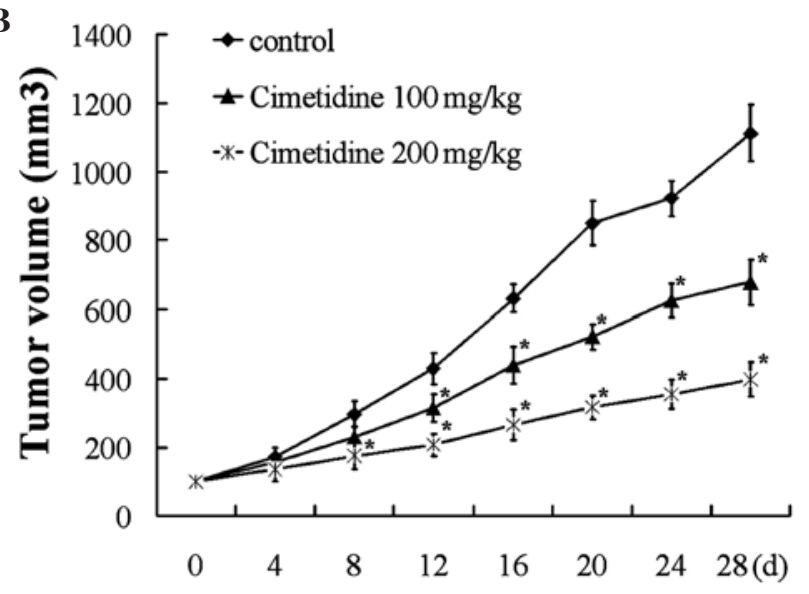

D

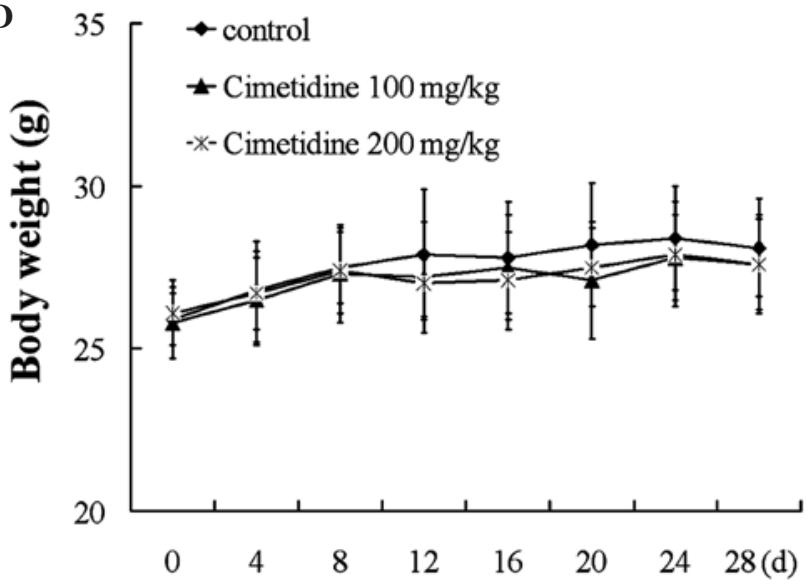

treatment also caused the proteolytic activation of caspases such as caspase-3, caspase- 8 and caspase- 9 in a dose-dependent manner (Fig. 4). Activated caspases induce limited proteolysis in a number of cellular proteins, which are degraded by the caspase family as a result of apoptosis. To test the physiological relevance of in vitro cimetidine-induced antitumor effects in vivo, the antitumor effects of cimetidine were evaluated in SGC-7901 xenografts. Cimetidine significantly inhibited tumor growth of the SGC-7901 xenografts without causing mortality, significant weight loss, or other noticeable major side effects. These observations are in agreement with our in vitro studies showing that treatment of gastric cancer cells with cimetidine results in a dose-dependent induction of apoptosis.

Apoptosis (programmed cell death), is a specific form of cell death characterized by several morphological and

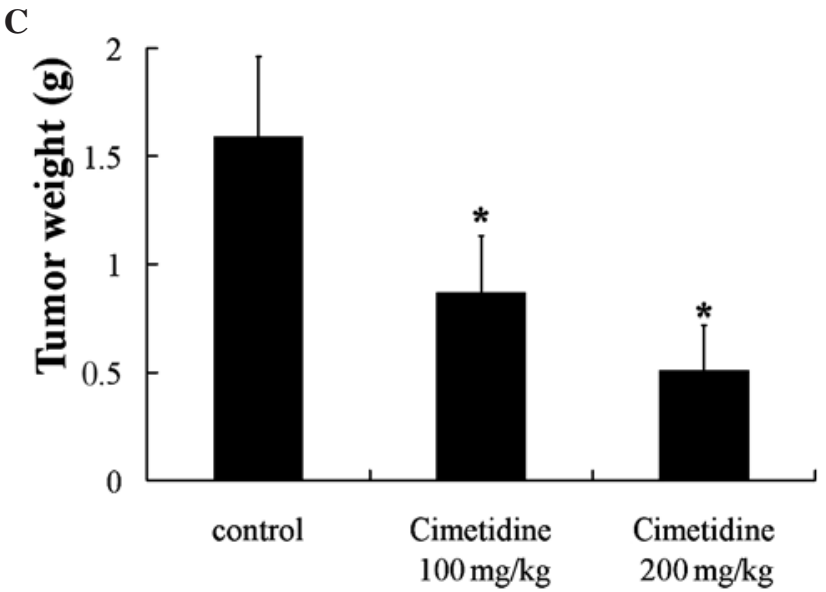

Figure 5. Inhibitory effect of cimetidine on the growth of transplantable tumors. (A) Photograph showing representative mice bearing SGC-7901 xenografts 6 weeks after 28-day treatment of cimetidine. (B) Tumor volume of control and cimetidine treatment groups. Tumor volume was measured once every 4 days. (C) Tumor weight of control and cimetidine treatment groups. After nude mice were treated for 28 days, tumors were isolated and weighed. (D) Body weight of control and cimetidine treatment groups. Body weight was measured once every 4 days. Each data point is the average from five mice (n), ${ }^{*} \mathrm{p}<0.05$ as compared to control.

biochemical events $(25,26)$. Apoptosis is a crucial event in a wide variety of biological processes including embryogenesis, organ, immune system and homeostatic system development $(27,28)$. Aberrant cell survival resulting from inhibition of apoptosis is expected to contribute to tumor progression and oncogenesis, and cancer cells often gain a selective growth advantage by blocking apoptosis (29). Therefore, the induction of apoptotic cell death is an important mechanism in anticancer properties of many anticancer drugs (30,31).

Two important groups of proteins involved in apoptotic cell death are the members of the Bcl-2 family (32) and a class of cysteine proteases known as caspase (33). The Bcl-2 family can be classified into two functionally distinct groups: antiapoptotic proteins and pro-apoptotic proteins. Bcl-2, an antiapoptotic protein, is known for regulating apoptotic pathways and protecting against cell death. Bax, a proapoptotic protein of that family, is expressed abundantly and 
selectively during apoptosis and promotes cell death. The Bcl-2 family regulates a common cell death pathway and functions at a point where various signals converge $(34,35)$. It has been found that the ratio of $\mathrm{Bax}$ to $\mathrm{Bcl}-2$ acts to regulate the susceptibility of cells to apoptosis (36). In our study, there was a dose-dependent decrease of Bcl-2 in cimetidinetreated gastric cancer cells, while the levels of Bax were increased, resulting in an increase in ratio of $\mathrm{Bax} / \mathrm{Bcl}-2$. These observations show that cimetidine-induced apoptosis in human gastric cancer cells was triggered by the downregulation of Bcl-2 and the up-regulation of Bax. It has been well established that caspase-mediated apoptosis in most cells is induced through the activation of either the mitochondrial (intrinsic) pathway or the death receptor (extrinsic) pathway (37). Death receptors, through adaptor molecules, recruit initiator caspase- $2,-8$ or -10 , while intrinsic death signals result in the activation of caspase-9. Initiator caspases are able to activate effector caspases (caspase-3, -6 and -7) and effector caspases are common to both the extrinsic and intrinsic death pathways (38). Both of these mechanisms will lead to the hierarchical activation of the caspase family, which are responsible for the characteristic morphological changes observed during apoptosis (39). Our investigation show that the molecular mechanisms involved in cimetidineinduced apoptosis of human gastric cancer cells, seemed to proceed via both the extrinsic and intrinsic pathway, as shown by activation of caspase- $8,-9$ and -3 .

In summary, our present findings indicate that cimetidine significantly inhibited growth of human gastric cancer cells SGC-7901 and MGC-803 by inducing apoptosis in a dosedependent manner, accompanied by an increase in Bax/Bcl-2 ratios and activation of caspases. Moreover, we demonstrated the tumor growth inhibition effect of cimetidine in a nude mouse model. Given the potential and safety of cimetidine, it is a promising candidate for therapy of gastric cancer, although additional studies are needed.

\section{Acknowledgements}

We thank Dr Tao Wu and Dr Di Na for their expert technical assistance in preparing cell culture and animal experiments.

\section{References}

1. Ozols RF, Herbst RS, Colson YL, et al: Clinical cancer advances 2006: major research advances in cancer treatment, prevention, and screening - a report from the American Society of Clinical Oncology. J Clin Oncol 25: 146-162, 2007.

2. Hohenberger P and Gretschel S: Gastric cancer. Lancet 362: 305-315, 2003.

3. Davis PA and Sano T: The difference in gastric cancer between Japan, USA and Europe: what are the facts? what are the suggestions? Crit Rev Oncol Hematol 40: 77-94, 2001.

4. Hansson LE, Sparén P and Nyrén O: Survival in stomach cancer is improving: results of a nationwide population-based Swedish study. Ann Surg 230: 162-169, 1999.

5. Yu W, Whang I, Suh I, Averbach A, Chang D and Sugarbaker PH: Prospective randomized trial of early postoperative intraperitoneal chemotherapy as an adjuvant to resectable gastric cancer. Ann Surg 228: 347-354, 1998.

6. Welage LS: Overview of pharmacologic agents for acid suppression in critically ill patients. Am J Health Syst Pharm 62 (Suppl): S4-S10, 2005.

7. Adams WJ and Morris DL: Short-course cimetidine and survival with colorectal cancer. Lancet 344: 1768-1769, 1994.
8. Morris DL and Adams WJ: Cimetidine and colorectal cancer old drug, new use? Nat Med 1: 1243-1244, 1995.

9. Kelly MD, King J, Cherian M, et al: Randomized trial of preoperative cimetidine in patients with colorectal carcinoma with quantitative assessment of tumor-associated lymphocytes. Cancer 85: 1658-1663, 1999.

10. Sasson AR, Gamagami R, An Z, Wang X, Moossa AR and Hoffman RM: Cimetidine: an inhibitor or promoter of tumor growth? Int J Cancer 81: 835-838, 1999.

11. Dexeus FH, Logothetis CJ, Sella A, Fitz K, Amato R, Reuben JM and Dozier N: Phase II study of coumarin and cimetidine in patients with metastatic renal cell carcinoma. J Clin Oncol 8: 325-329, 1990.

12. Morton RF, Creagan ET, Cullinan SA, Mailliard JA, Ebbert L, Veeder $\mathrm{MH}$ and Chang $\mathrm{M}$ : Phase II studies of single-agent cimetidine and the combination N-phosphonacetyl-L-aspartate (NSC-224131) plus L-alanosine (NSC-153353) in advanced malignant melanoma. J Clin Oncol 5: 1078-1082, 1987.

13. Lefranc F, Yeaton P, Brotchi J and Kiss R: Cimetidine, an unexpected anti-tumor agent, and its potential for the treatment of glioblastoma. Int J Oncol 28: 1021-1030, 2006.

14. Tønnesen H, Knigge U, Bülow S, et al: Effect of cimetidine on survival after gastric cancer. Lancet 2: 990-992, 1988.

15. Lawson JA, Adams WJ and Morris DL: Ranitidine and cimetidine differ in their in vitro and in vivo effects on human colonic cancer growth. Br J Cancer 73: 872-876, 1996.

16. Reynolds JL, Akhter J and Morris DL: In vitro effect of histamine and histamine $\mathrm{H} 1$ and $\mathrm{H} 2$ receptor antagonists on cellular proliferation of human malignant melanoma cell lines. Melanoma Res 6: 95-99, 1996.

17. Hahm KB, Kim WH, Lee SI, Kang JK and Park IS: Comparison of immunomodulative effects of the histamine-2 receptor antagonists cimetidine, ranitidine, and famotidine on peripheralblood mononuclear-cells in gastric-cancer patient. Scand J Gastroenterol 30: 265-271, 1995.

18. Adams WJ, Morris DL, Ross WB, Lubowski DZ, King DW and Peters L: Cimetidine preserves non-specific immune function after colonic resection for cancer. Aust N Z J Surg 64: 847-852, 1994.

19. Kobayashi K, Matsumoto S, Morishima T, Kawabe T and Okamoto T: Cimetidine inhibits cancer cell adhesion to endothelial cells and prevents metastasis by blocking E-selectin expression. Cancer Res 60: 3978-3984, 2000.

20. Matsumoto S, Imaeda Y, Umemoto S, Kobayashi K, Suzuki H and Okamoto $\mathrm{T}$ : Cimetidine increases survival of colorectal cancer patients with high levels of sialyl Lewis-X and sialyl Lewis-A epitope expression on tumour cells. Br J Cancer 86: 161-167, 2002.

21. Rajendra S, Mulcahy H, Patchett S and Kumar P: The effect of $\mathrm{H} 2$ antagonists on proliferation and apoptosis in human colorectal cancer cell lines. Dig Dis Sci 49: 1634-1640, 2004.

22. Fukuda M, Tanaka S, Suzuki S, Kusama K, Kaneko T and Sakashita H: Cimetidine induces apoptosis of human salivary gland tumor cells. Oncol Rep 17: 673-678, 2007.

23. Fukuda M, Kusama K and Sakashita H: Cimetidine inhibits salivary gland tumor cell adhesion to neural cells and induces apoptosis by blocking NCAM expression. BMC Cancer 8: 376-389, 2008.

24. Debatin KM: Apoptosis pathways in cancer and cancer therapy. Cancer Immunol Immunother 53: 153-159, 2004.

25. Hengartner MO: The biochemistry of apoptosis. Nature 407: 770-776, 2000.

26. Saraste A and Pulkki K: Morphologic and biochemical hallmarks of apoptosis. Cardiovasc Res 45: 528-537, 2000.

27. Meier P, Finch A and Evan G: Apoptosis in development. Nature 407: 796-801, 2000.

28. De Alborán IM, Robles MS, Bras A, Baena E and Martínez-A C: Cell death during lymphocyte development and activation. Semin Immunol 15: 125-133, 2003.

29. Hanahan D and Weinberg RA: The hallmarks of cancer. Cell 100: 57-70, 2000 .

30. Deigner HP and Kinscherf R: Modulating apoptosis: current applications and prospects for future drug development. Curr Med Chem 6: 399-414, 1999.

31. Sporn MB and Suh N: Chemoprevention of cancer. Carcinogenesis 21: 525-530, 2000.

32. Korsmeyer SJ: BCL-2 gene family and the regulation of programmed cell death. Cancer Res 59: S1693-S1700, 1999.

33. Cohen GM: Caspases: the executioners of apoptosis. Biochem J 326: 1-16, 1997. 
34. Earnshaw WC, Martins LM and Kaufmann SH: Mammalian caspases: structure, activation, substrates and functions during apoptosis. Annu Rev Biochem 68: 383-424, 1999.

35. Adams JM and Cory S: Life-or-death decisions by the Bcl-2 protein family. Trends Biochem Sci 26: 61-66, 2001.

36. Korsmeyer SJ, Shutter JR, Veis DJ, Merry DE and Oltvai ZN: Bcl-2/Bax: a rheostat that regulates an anti-oxidant pathway and cell death. Semin Cancer Biol 4: 327-332, 1993.
37. Green DR: Apoptotic pathways: paper wraps stone blunts scissors. Cell 102: 1-4, 2000.

38. Ashe PC and Berry MD: Apoptotic signaling cascades. Prog Neuropsychopharmacol Biol Psychiatry 27: 199-214, 2003.

39. Barrett AJ and Rawlings ND: Evolutionary lines of cysteine peptidases. Biol Chem 382: 727-733, 2001 